\title{
A szemléletváltás szükségességéről - Helyzetjelentés az 1960-as évek egészségfejlesztő szakemberképzéséről
}

\author{
About the need for a changing approach - Status report on the \\ training of health promotion specialists in the 1960s
}

Szerző: Prievara Dóra Katalin $\triangle$

Szegedi Tudományegyetem, Juhász Gyula Pedagógusképző Kar, Alkalmazott Egészségtudományi és Egészségfejlesztési Intézet

Beküldve: 2019. 12. 09.

doi: $10.24365 /$ ef.v60i5.546

Kulcsszavak: egészségfejlesztés; orvosképzés; prevenció

Keywords: health promotion; medical school; prevention

Napjainkban számos olyan hírrel találkozhatunk, ami riasztó adatokkal, elkeserítő helyezésekkel elemzi a hazai és nemzetközi népegészségügyi állapotokat. De miként alakult ez korábban? Milyen utalásokat találunk az Egészségfejlesztés folyóirat korábbi számaiban arra vonatkozóan, hogy egyre nagyobb szükség van az egészségfejlesztő szakemberek képzésére, az egészséggel kapcsolatos szemléletmódbeli váltásra?

Zsebők Zoltán a Tudományos Ismeretterjesztő Társaság egészségügyi szakosztályának 1964-ben rendezett Első Országos Vándorgyúlésen tartott megnyitó beszédében hangsúlyozta, hogy a betegségek elleni küzdelemben (eddig) megtett út hosszú és rögös volt, és hatalmas lépéseket tett a tudomány a tömegjárványok leküzdése érdekében, forradalmi kutatásokkal számos betegség már gyógyíthatóvá és visszafordíthatóvá vált. ${ }^{1}$ Emellett azonban külön hangsúlyozza a felvilágosító és megelőző munkát végzők fontos szerepét, melyet a sorkatonasághoz hasonlított: ők alkotják ugyanis az orvosok és kutatók hadseregét, ők „az élet hadserege", akik újra és újra harcba szállnak az emberek egészségéért.

Ahogy a prevenció egyre inkább elótérbe került, az orvosi gondolkodás megváltozásának szükségességét is maga után vonta, kezdve az egyetemi oktatás megújításával², amivel a cél a szociálhigiénés és a betegség megelőzésére irányuló szemléletmód kialakítása lehet. ${ }^{3}$ Az orvos gyógyító szerepe mellett egyre inkább hangsúlyosabbá váltak a szúrővizsgálatok, a helyesen kialakított életmód szerepe és a következetes egészségnevelés. Erősödött a felismerés, hogy egyre többet kell tenni tehát az egészség védelme érdekében, az egészség megőrzéséért - hiszen már nem pusztán a betegségek gyógyítása a feladat, így egyre aktuálisabb kérdéssé vált az egészségnevelés egyetemi szintû oktatása, melyet 1961-től az Egészségügyi Minisztérium utasítása szabályozott. Ennek következtében a hazai orvos-, fogorvos és gyógyszerészképzésben már helyet kapott a közegészségtan és járványtan tantárgy keretein belül a felvilágosítás jelentősége, a mentálhigiéné, a hallgatók életmódja és a szűrések - bár mindössze 2 óra volt az elméleti és 3 óra a gyakorlati bemutatásra szánt időkeret. Az egészségnevelés pusztán érintőlegesen került elő az egyetemi klinikai előadások során, míg a gyakorlati tapasztalatok megszerzésére több lehetőség is nyílt az orvostanhallgatók előtt: falusi felvilágosító előadások tartása, üzemi és iskolai szűrővizsgálatok, illetve a kórházi gyakorlatok során az orvos-beteg találkozók. Megfogalmazódott azonban az igény az egészségnevelési ismeretek alaptárgyban való oktatására, amely olyan célkitǔzéseket foglal magában, mint (1) a beteg életvezetésének helyes kialakítása, 
(2) az orvosok kórházon kívüli tevékenységeinek alakítása, (3) a beosztottak szemléleti nevelése, (4) az orvos saját mentálhigiénés állapotának ismerete. Mindez azonban csak úgy valósulhat meg a gyakorlatban is, ha minden tantárgyban megjelenik az egészségnevelési szemlélet. Érdemes megemlíteni, hogy az egészségügyi felvilágosítás tömeges oktatására a továbbképzés adott inkább lehetőséget, ugyanis a vidéki körzeti orvosok számára két hónapos egyéni kórházi továbbképzés volt az előírás.

Azonban nem kizárólag a leendő orvosok számára volt fontos az egészségfejlesztéssel kapcsolatos ismeretek elsajátítása. A hazai gyermekápolónőképzésben az egészségügyi felvilágosítás önálló, 10 órás tantárgyként volt jelen az 1968/69-es tanévig, majd azt követően a közegészségtan tantárgyban kapott helyett. ${ }^{4} \mathrm{Az}$ átalakítást az indokolta, hogy az oktató orvos legyen, aki képes felhívni a figyelmet a különböző szaktárgyak egészségnevelési vonatkozásaira, a kapcsolódási pontokra. A tematika összeállításánál fontos szempont volt a hallgatók bevonása és aktivizálása, a tantárgy során szükséges volt az írásbeli dolgozat mellett plakátot/röplapot szerkeszteni és próbaelőadást tartani különböző témakörökben, különböző csoportoknak (iskolásoknak, várandós anyáknak, beteg gyermeküket ápoló szülőknek). Továbbá az egészségügyi szakiskolák középkáderképzésben tanulóinak is feladatuk volt az egészséggel kapcsolatos oktatónevelő tevékenységek végzése. ${ }^{5}$ Éppen ezért az oktatásuk során érintették az egészségvédelmet és az egészségnevelés témaköreit. Ebbe beletartozott a saját egészségükkel kapcsolatos ismeretek és követendő szokások elsajátítása, valamint különböző módszerekkel mindezek továbbadása, átadása mások számára is.

A Szovjetunióban az orvosegyetemeken az egészségügyi felvilágosítás az egészségügyi szervezés tárgyához tartozott. ${ }^{6} \mathrm{~A}$ tanterv 10 órás előadást írt elő, ami a nyári gyakorlatok helyszínéül szolgáló kórházakban kiegészült empirikus tapasztalatokkal, mivel ilyenkor a hallgatóknak feladatuk volt a lakosság különböző rétegei számára előadásokat és tanfolyamokat tartani. További nemzetközi tapasztalatokról számolt be Sz. Fodor Katalin 1966-os tájékoztatója. ${ }^{7}$ Ebben az időszakban az amerikai oktatási rendszerben már lehetőség volt főiskolai szintű, a középiskolát követő négyéves képzésben egészségügyi nevelői ("Bachelor of health education") fokozatot szerezni, és többnyire egészségtan tanárként elhelyezkedni, iskolai egészségügyi nevelésre képződni. A Harvard Egyetemen már közegészségügyi szakemberképzés folyt, éves szinten száz hallgatóval, akik általában külföldről érkeztek, és az egyetemi diploma mellett lehetőségük nyílt doktori fokozat megszerzésére is egyénre szabott kutatások és terepmunkák elvégzésével. A külföldi hallgatók disszertációjának minden esetben az anyaország egészségügyi nevelési problémáját kellett vizsgálnia, elméleti és gyakorlati szinten egyaránt. Az összes amerikai egészségügyi nevelési szakembereket képző egyetemre jellemző volt a multidiszciplináris szemléletmód, a szoros együttmúködés a közegészségügyi, a felnőttnevelési és a nevelési intézetekkel, ami a jövőben követendő jó példaként szolgált más képzések számára is.

\footnotetext{
${ }^{1}$ Zsebők Z. Orvostudomány és egészségügyi ismeretterjesztés. Egészségügyi Felvilágosítás. 1965;6:3-4.

${ }^{2}$ Vértes L. Az egészségnevelés egyetemi oktatásáról szigorló orvosi szemmel. Egészségügyi Felvilágosítás. 1969;10:249-252.

${ }^{3}$ Fodor F. Az egészségügyi nevelés az orvosképzésben. Egészségügyi Felvilágosítás. 1966;7(1):13-15.

${ }^{4}$ Simon T. Az egészségnevelés oktatásának tapasztalatai gyermekápolónőképző iskolában. Egészségügyi Felvilágosítás. 1970;11:38-40.

${ }^{5}$ Galvács M. Az egészségnevelés oktatása az egészségügyi szakiskolában. 280-282. 1968;9:280-282.

${ }^{6}$ Bartha F. Az egészségügyi felvilágosítás oktatása az egészségügyi dolgozók képzésében és továbbképzésében. Egészségügyi Felvilágosítás. 1964;4:24-34.

${ }^{7}$ Sz. Fodor K. Az egészségügyi felvilágosítás szakembereinek képzése az Amerikai Egyesült Államokban. Egészségügyi Felvilágosítás. 1966;7(3):136-140.
} 